Matgorzata Warchat

University of Rzeszow*

iD https://orcid.org/0000-0002-7134-456X

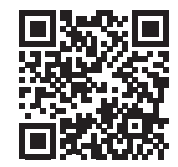

\title{
"She Cuppeth the Lightning in her Hand": Spirituality, Domination, and Violence in The Power (2016) by Naomi Alderman
}

\begin{abstract}
The Power by Naomi Alderman offers a dystopian vision of the world in which girls and women develop the ability to produce electric current. The power is both a blessing and a curse since it enables women to stand up to oppression and upturn male dominance, but also turns their bodies into lethal weapons. The following article aims to analyse depictions of women and girls in the novel while taking into consideration their entanglement in religion, organised crime, and politics. The analysis includes two perspectives, ecofeminist and posthuman. The power, on the one hand, can be seen as an emblem of rediscovered interconnection between people and the forces of nature or animals. On the other hand, the depictions of women make them resemble cyborgs, combinations of living organisms and machines. Moreover, the article comments on the utopian potential of the world presented in the novel, and on the dystopian outcomes of the described shift of power.
\end{abstract}


* Department of English Studies, Institute of Modern Languages, University of Rzeszow Al. Mjr. W. Kopisto 2B, 35-315 Rzeszów e-mail:malgwar11@gmail.com 


\section{Introduction}

Naomi Alderman's 2016 novel, The Power, offers a harrowing vision of the world in which, as a side-effect of environmental pollution, girls develop an organ called the skein, which allows them to discharge electric current and pass this ability on to older women. The growth of the skein and the girls' increasing awareness of their abilities lead to the Day of the Girls, a series of worldwide rebellions targeted against patriarchal oppression. Ultimately, this power shift does not lead to a matriarchal utopia, but the world which emerges is that of violence and asymmetrical power relations. The novel outlines the events which happen before the Day of the Girls, focusing on the lives of the central characters and their discoveries of the new abilities. The Day of the Girls itself is documented by a young self-taught journalist, Tunde, who streams its course of events online. The aftermath of the series of uprisings is presented using the example of Moldova, but the global outcome is also outlined. The final setting is an imaginary future in which a fictional male author is attempting to publish a historical novel on life before a global disaster called the Great Cataclysm.

The following article aims to analyse the depictions of women and girls endowed with the power using the example of three female characters, Allie, Roxy, and Margot, as well as to trace the perception of women and their role in the society following their views on the titular power. In order to analyse the contradicting and complex attitudes, two perspectives, posthuman and ecofeminist, are applied. Secondly, the article attempts to answer the question why the potentially constructive revolution results in a dystopian, rather than a utopian, vision of the world which emerges after the Day of the Girls and the Cataclysm.

\section{The properties and origin of the titular power}

Although a definitive cause of the power is not fully explained, it can be assumed that one hypothesis about the origin of the phenomenon outweighs other speculations. In the novel, scientists and environmentalists believe that such changes to women's bodies and resultant abilities are a consequence of Guardian Angel, a substance released into supplies of drinking water during the Second World. The substance was supposed to protect civilians from nerve agent attacks. Guardian Angel gradually spread and polluted seas up to the point when the environmental build-up of this substance led to a mutation (Alderman 2016: 150). The novel presents several other theories as to the origin of the power, such as that "the development of 
this organ in humans is proof positive of the aquatic-ape hypothesis" (Alderman 2016: 28) and that humans originate from such sea creatures as the electric eel or the electric ray. Secondly, some reports of scientists who believe that the ability has always been present, though inactive, in the human genome are mentioned. Apart from more scientific and rational theories, the appearance of the power is also interpreted by religious groups as a sign of the impending apocalypse: "Preachers and televangelists grab the news and squeeze it, finding in the sticky entrails the unmistakable signs of the impending end of days" (Alderman 2016:28).

The skein, an organ responsible for the production of the power, is a strip of twisted striated muscles located across the collarbones: "At the points of the collar are electro-receptors enabling [...] a form of electric echo-location" (Alderman 2016: 28). Importantly, the organ cannot be removed without killing or severely injuring a woman or girl. However, the properties of the skein suggest that it is more than an effective defence mechanism, since the electric current " $[\ldots]$ particularly affects the pain centres of the human brain $[\ldots]$, meaning that, while it looks like electrocution, it hurts more than it needs to. It is a targeted pulse which sets up a response in the body's pain receptors" (Alderman 2016: 33). The skein and its properties, thus, seem to be not only an anti-predator adaptation used to ward off attacks but also a weapon which specifically targets other humans. The growth of the skein is observed in younger girls and increases from generation to generation: "They are present in increasingly large proportions of women with every birth-year that passes. Women who were about thirteen or fourteen years old around the Day of the Girls almost invariably possess a full skein" (Alderman 2016: 151). Younger women and girls play a large role in the distribution of the skill. The power can be awakened in older women by passing a gentle controlled amount of electricity to stimulate their, often weaker or underdeveloped, skeins.

Despite the lack of a definitive answer to the question of its origin, many properties of the power, importantly, its shape and direction, are presented in a fictional manuscript called The Book of Eve and apocrypha excluded from it. The shape of the power is often likened to elements of non-human nature such as trees, river estuaries or bolts of lightning: " $t \mathrm{t}] \mathrm{he}$ shape of power is always the same; it is the shape of a tree. Root to tip, central trunk branching and re-branching, spreading wider in ever-thinner searching fingers" (Alderman 2016: 11). Often, these descriptions highlight the animate properties of the power: "[ $t]$ he shape of power is the outline of a living thing straining outward, sending its fine tendrils a little further, and a little further yet" (Alderman 2016: 11). Hence, not only is the act of producing the power described as purposeful, but the power itself seems to behave as if it were a living organism: "[w]e send electric currents down orderly runs of circuits and switches, but the shape that electricity wants to take is of a living thing, a fern, a bare branch. The strike point in the centre, the power seeking outward" (Alderman 2016: 11). What also suggests the connection of the power with non-human nature, rather than with the man-made world, are several descriptions which imply that the electric jolts smell like wet leaves after a storm or ripe fruit.

However, such similes are not limited only to the non-human world. The shape of the power also resembles the human nervous system and this comparison links what is human to non-human:

This same shape grows within us, our inward trees of nerves and blood vessels. The central trunk, the pathways dividing and redividing. The signals carried from our fingers' ends to the spine to the brain. We are electrical. The power travels within us as it does in nature. (Alderman 2016:11) 
Moreover, the movement of the power, from the younger to the older, is compared to migrations of people and their means of communication: "Power travels in the same manner between people [...] Orders travel from the centre to the tips. Results travel from the tips to the centre" (Alderman 2016: 11). Through such comparisons, The Book of Eve apocrypha establishes human beings as a part of the non-human world and its unpredictable laws but serves as a reminder about the fuzzy boundaries between nature and culture.

The discovery of the power becomes a uniting experience for women around the globe. Bewildered by their new abilities women gather in groups to discover their scope and practice them. The power becomes an opportunity for a social revolution and a chance for women to take their lives and political power into their own hands, organise, and take over oppressive institutions. Hence, Allie presents this potential as not only uniting but also revolutionary:

It follows that there are two ways for the nature and use of human power to change. One is that an order might issue from the palace, a command unto the people saying 'It is thus.' But the other, the more certain, the more inevitable, is that those thousand thousand points of light should each send a new message. When the people change, the palace cannot hold. (Alderman 2016:12)

The Day of the Girls and subsequent demonstrations of the power are presented as a liberating experience for women in developing countries, especially to those previously underprivileged, impoverished or exploited. This new natural ability promises women a permanent transformation of the world they live in; however, ultimately, the revolts do not bring about any peaceful outcomes.

\section{The power as an interconnection: an ecofeminist perspective}

One of the most significant characters in the novel, Allie, represents both a spiritual and ecofeminist approach towards the power. When she is introduced to the readers nine years before the cataclysm, Allie Montgomery-Taylor is an American teenager who escapes from a severely abusive foster family and starts a group of girls and, eventually, a cult in a convent orphanage under the assumed name Mother Eve. Allie, as a charismatic speaker, encourages the girls to practice their power and use it to stand up to the nuns and authorities. Mother Eve's followers are often young women with experiences of domestic abuse, neglectful families or underprivileged backgrounds. With time, and with the help of the Internet and social media, the cult attracts many followers among girls and women who have just discovered or perfected their power.

Allie's teachings, inspired by the voice she hears in her head, encourage her followers to embrace the feminine history of world religions:

Jews: look to Miriam, not Moses, for what you can learn from her. Muslims: look to Fatimah, not Muhammad. Buddhists: remember Tara, the mother of liberation. Christians: pray to Mary for your salvation. (Alderman 2016: 138)

In her speeches, she frequently uses paraphrased verses from religious scriptures, mostly the Bible, which she feminises by the change of pronouns referencing God. For instance, "She cuppeth the lightning in her hand. She commandeth it to strike" (Alderman 2016: 16) is almost a direct quote from the Book of Job (Job 36: 32), but the pronoun he, referring to God, is replaced with she, referring now to a woman. This strategy aims to reconceptualise monotheistic, patriarchal religions such as Judaism, Christianity, and Islam as less hostile to 
women by turning to goddesses or female deities instead of male gods. Allie's reinterpretation of rigid religious traditions means to spiritually empower women brought up in oppressive patriarchal cultures but also an attempts to reclaim the frequently overlooked female religious figures. Most importantly, though, it is a sign of a clear rejection of all aspects of patriarchal moral and spiritual authority.

Importantly, Allie, as Mother Eve, emphasises not only the interconnection between humans and non-human nature but also proposes the immanent existence of the divine in every woman, counteracting the stigma related to the female body present in many religions. To Allie, the power, both as an ability and a reminder of an interconnection, seems to be equivalent to the Christian notion of the soul:

You have been taught that you are unclean, that you are not holy, that your body is impure and could never harbour the divine. You have been taught to despise everything you are and to long only to be a man. But you have been taught lies. God lies within you, God has returned to earth to teach you, in the form of this new power. Do not come to me looking for answers, for you must find the answers within yourself. (Alderman 2016: 138)

Allie's teachings can be associated with spiritual ecofeminism, defined by Maria Mies and Vandana Shiva (2014: 17) as "the desire to recover, to regenerate [a close relationship with nature] as a means to liberate women and nature from patriarchal destruction". In their understanding of this term, spirituality is perceived as a realisation of this interconnectedness. According to Greta Gaard (2016: 68), it is the ecofeminist recognition of interbeing "that bridges socially constructed boundaries of class, race, species, sexuality, gender, age, ability, nation, and more - and an «entangled empathy» that brings both compassion and action to the task of alleviating conditions of eco-social injustice". Women from the novel, having gained the powers of both nature and the divine, can now protect themselves from patriarchal abuse and discrimination. Their new abilities also grant women rights to bodily selfdetermination. Even though the novel focuses on the appropriation of women's bodies rather than non-human animal bodies, what connects them in the novel are images of shackled chickens kept by Allie's foster family for meat and descriptions of victims of sex trafficking escaping capture by using their power. Those images illustrate the ecofeminist concern for the exploitation of both female and non-human bodies, as explained by Gaard (2016: 71): "Women's right to bodily self-determination [...] becomes an ecological issue [...] in a context of economic globalization that continues social, political, economic, and gendered forms of colonization that appropriate women's bodies and environmental bodies alike". The images of the exploitation and appropriation of human and non-human bodies indicate shared vulnerabilities. In The Death of Nature, Carolyn Merchant lists several of them, including the exploitation and suffering caused by militarism, capitalism and scientific progress or the view of both as recreational resources (Merchant 1989: xxi). Moreover, as further noticed by Merchant:

Anthropologists have pointed out that nature and women are both perceived to be on a lower level than culture, which has been associated symbolically and historically with men. Because women's physiological functions of reproduction, nurture, and childrearing are viewed as closer to nature, their social role is lower on the cultural scale than that of the male. Women are devalued by their tasks and roles, by their exclusion from community functions whence power is derived, and through symbolism. (1989: 144) 
Ecofeminism reclaims this pairing of women and nature and in so doing opposes the patriarchal hierarchy and power structures. Some recommendations with which Merchant (1989: 295) concludes her book, such as decentralisation of non-hierarchical forms of organisation, are Allie's initial goals and intentions.

Allie's vision of the place of women in the new, post-day-of-the-girls world is initially relatively non-violent and seems to aim at a peaceful, sustainable existence in a society shaped by women, led by the principle of interconnectedness. However, when observing a tank of electric eels in an aquarium, Allie notices that the power can be used as a defence mechanism against former oppressors, but also as a deadly weapon when she realises that "[the eels] can «remote control» the muscles in their prey by interfering with the electric signals in the brain. They can make those fish swim straight into their mouths if they want to" (Alderman 2016: 48). This idea encourages her to practice the newly acquired skills but also serves as a reminder that the power may be used to intentionally hurt and manipulate others. Although not malevolently, Allie uses her power to fake "miracles" when she sends the electric current through the bodies of people with different diseases to temporarily ease the pain.

\section{The power as the property of a posthuman cyborg}

In Alderman's novel, the power can be interpreted not only as a phenomenon which connects humans with non-human nature but also as a connection with other non-human agents such as technology. The exploration of the relationship between the human and the "technological other", but also challenging the demarcation lines between the organic and the inorganic constitute some of the key interests of posthumanism (Braidotti 2013: 89). While from the ecofeminist perspective, the power seems to be a sign of interconnection between people and non-human animals, such as electric eels, a posthuman perspective allows viewing the girls and women presented in the novel as cyborgs.

Such an interpretation can be best illustrated by the examples of characters involved in politics and organised crime, Margot and Roxy. Margot Cleary is an American politician, mayor of a large city and mother of a teenage daughter. It is the daughter, Jocelyn, who awakens her power. Margot establishes Northstar, a net of military camps for girls to raise an army of female mercenaries. Although she claims that her goal is to teach girls how to use their power safely, she secretly hopes to gain political capital and money. Roxy Monke is a British teenager whose family is involved in organised crime. She first uses the power at the age of fourteen when attacked by a rival gang. Very strong both physically and mentally, Roxy embarks on a mission to avenge her mother's death. When she joins Mother Eve and her followers as a "solider", she instructs other girls on the effective use of the power. Because of her abilities, she quickly becomes the strongest member of her crime family and uses it to her advantage in her vendetta. However, it is soon revealed that her family sees her as a killing machine and her skein as a valuable machine part. When they learn it is possible to steal and transplant it, possibly killing Roxy, they do not hesitate. In both cases, the female body is appropriated and repurposed as a lethal weapon. As a consequence of Margot's institution or Roxy's tutoring, girls all around the world learn how to use their power as an instrument of death or torture. It is not only the people who plan to gain from the girls' power but also the girls themselves who start to consider themselves killing machines, reminiscent of superheroes and mutants in comic books. From this perspective, the girls and women who 
are capable of producing electricity seem to transcend the boundary between what is conventionally considered human and human-made.

Donna Haraway in her essay "A Cyborg Manifesto" states: "By the late twentieth century, our time, a mythic time, we are all chimeras, theorized and fabricated hybrids of machine and organism - in short, cyborgs" (Haraway 2016: 6). In The Power, women and girls gain the skills associated mostly with machines and human-made inventions. Although the girls and women are physically human, their abilities go beyond what is expected from a human body and, importantly, considered safe to possess. Donna Haraway defines a cyborg as "a high-tech imaginary, where electronic circuits evoke new patterns of interconnectedness and affinity" (Braidotti 1994: 3). Such a vision proposes radical changes in understanding life in terms of species and contests the culture-nature opposition. Moreover, it proposes a positive, affirmative view of the interconnection between people and machines as well as between people and non-human nature and suggests possibilities for new forms of collective coexistence with possible benefits for humanity. In her book, The Posthuman, Rosi Braidotti develops this definition of a cyborg beyond the realm of the imaginary creatures of science fiction or humanmachine chimaeras: "cyborgs include not only the glamorous bodies of high-tech, jet-fighter pilots, athletes or film stars but also the anonymous masses of the underpaid, digital proletariat who fuel the technology-driven global economy without ever accessing it themselves" (Braidotti 2006: 90). Certainly, many girls and women portrayed by Alderman come from underprivileged backgrounds or are representatives of the dispossessed, underpaid proletariat or precariat. For them, the power offers a possibility to improve their social status through a violent rebellion.

In the novel, however, the power's involvement in politics, organised crime and forms of organised religion does not allow for the permanent formation of such communities. Apart from Mother Eve's teachings, the use of the power is not affirmative of life and communitybuilding but monetised for financial and political gain. The girls and women from the novel can be considered bound or exploited cyborgs. It is the use of the power and consequently women's lives and bodies for profit that makes it impossible to form strong communities, based on the understanding of their new position and the interconnection, interbeing and collective strength.

\section{Dystopian outcomes of the power}

The novel presents short- and long-term consequences of the Day of the Girls, both globally and locally. The event brings about fear and insecurity: boys are taken to school in boys-only buses, the Internet is teeming with videos of girls injuring or even killing boys and men, male specialists on security propound to confine girls in maximum-security facilities, companies come up with inventions which are supposed to protect men from an attack. The Day of the Girls also leads to a change of the perception of femininity; its certain attributes, for instance, clothing, become associated with power and dominance: "Boys dressing as girls to seem more powerful. Girls dressing as boys to shake off the meaning of the power, or to leap on the unsuspecting, wolf in sheep's clothing" (Alderman 2016: 84). With time, on a global scale, women take over prestigious professions, as men's work (for example journalistic footage) is often attributed to women. Finally, violence and sexual violence against men become widespread. 
In Moldova, initially presented in the novel the primary country of origin for victims of human trafficking and a brutal dictatorship, the victims use their power to escape, and a military coup turns the country back to a violent dictatorship, but led by a woman. The new dictator, Tatiana Moskalev, encourages violence against men and introduces several restrictions, for instance, men cannot travel without a female companion, vote, drive cars, own businesses, and hold public or private gatherings. Wartime sexual violence is commonplace during and after the coup. Sexual assault and brutal rapes, as demonstrations of power and acts of revenge, are committed by women who raid hiding places of men who attempt to escape the country. The ensuing chaos is curbed by the Cataclysm, probably a detonation of an atomic bomb. Allie, when she acknowledges the atrocities committed by women and realises the hopeless situation of those who turned to extreme violence, decides that the only way for women to win is actually for humans to restore civilisation after an event of mass destruction.

From the letters of the fictional male author of the story emerges the world after the Cataclysm. An exchange of letters between the author and his female publisher reveals a deeply-sexist culture, in which men are objectified, dismissed, and patronised. For instance, the publisher comments on some fragments of the story: "I see you've included some scenes with male soldiers, male police officers and boy crime gangs, just as you said you would, you saucy boy! I don't have to tell you how much I enjoy that sort of thing" (Alderman 2016: 10). Moreover, the publisher's tone towards the author is consistently patronising and berating. Finally, the author is forced to publish his book under a female pen name.

Not only the reality of post-coup Moldova but also the world which emerges after the Cataclysm can be considered dystopian. Although the novel seems to lack the genre-typical outsider or insider crashed by the dystopian society (Moylan 2000: 14), the fictional male author of the novel himself can be perceived as such. The vision of the post-apocalyptic future presented in the novel, even though relatively close to the twenty-first-century reality, is probably meant to have the same didactic goal as utopian and dystopian novels, as defined by $\operatorname{Mohr}(2007: 7)$ :

In very general terms, utopia and dystopia foreground socio-political issues and strive to move the reader to a more critical awareness, and to compare unfavourably his or her own society to the future society (in the case of utopia) or to recognize tendencies in contemporary society that might lead, if continued, to the very dystopia s/he just read about. Utopian and dystopian literature thus desires a consciousness raising, if not the readers' active engagement in bringing on change.

The situation of the fictional author is meant to reflect the situation of women under patriarchy, but also to illustrate the systemic nature of sexism, since, as pointed out by Moylan (2000: xxi), "dystopia's foremost truth lies in its ability to reflect upon the causes of social and ecological evil as systemic". Thus, the depiction of the imaginary future society "elsewhere" (Moylan 2000: xiii) aims to provide reflections about the evils of the present time. The reality of the novel, though, is not based solely on basic ideas which often inspire dystopian discourse, recognised by Fatima Vieira (2010: 18) as "on the one hand, the idea of totalitarianism; on the other hand, the idea of scientific and technological progress which, instead of impelling humanity to prosper, has sometimes been instrumental in the establishment of dictatorships". The changes of the human genome which led to the Day of the Girls were not a direct result of scientific attempts to augment the properties of human bodies, but rather a random and unexpected side-effect. The totalitarian regime of Moldova, on the other hand, seems not to 
be an expression of the fear of totalitarianism, but rather an observation about old, brutal power-structures being replaced by similar, or even worse, ones. The gender-role reversed dystopia of the novel's future is then meant as a close reflection of the reality of the twentyfirst century.

\section{Conclusions}

Although the novel contains a significant amount of utopian potential, such as the possible recognition of interconnection of humans with either the natural world or machines, the final vision of the world after the Great Cataclysm is very far from ideal. The gender-reversal scenario mimics the treatment of women under different stages of patriarchy and suggests that the present is equally dystopian as the imaginary future. This weak point of the novel, namely the realisation of such a gender-reversed scenario, however, highlights the squandered utopian opportunities of the world presented in the novel. The possible new bonds between people, technology and the non-human world suggested by the ecofeminist and posthuman perspectives do not become reality, possibly because of the political, financial and territorial gains which the power allowed for. Certainly, the vision of the powerful cyborg and the power imbalance it created outweighs the peaceful opportunities of coexistence.

To end with, in "A Cyborg Manifesto" Donna Haraway (2016: 5) states that "the boundary between science fiction and social reality is an optical illusion". In Alderman's novel, the violence and discrimination against men after women realise their power is not very much different from what women have suffered under patriarchy in many points in history. Hence, The Power can, on the one hand, be treated as a "what if" story, where the subject of scrutiny is the reversal of gender roles enabled by a sudden and destructive ability. On the other hand, it can be read as a revenge narrative inspired, for instance, by the early onset of the global \#MeToo movement. The third possible, and most likely, interpretation is that The Power is a novel about missed opportunities for an imagined utopia, a tale of a forlorn chance for a world of gender equality.

The narratives of interconnection inspired by the ideas of peaceful coexistence in Mother Eve's teachings remain just apocrypha to a religious manuscript. The revolution itself follows old patterns of taking with force and defeating the enemy, not a constructive, positive change. As a result, the power imbalance remains the same, while old patterns are not dismantled but reversed. Because of the sudden shift of power, domination passes from the hands of one oppressor to the other. Finally, the fact that the novel offers hardly any redeeming qualities to the new world of female dominance highlights the importance of lost utopian opportunities. 


\section{Bibliography}

Alderman Naomi (2016), The Power, Penguin Random House, London.

Braidotti Rosi (1994), Nomadic Subjects: Embodiment and Sexual Difference in Contemporary Feminist Theory, Columbia UP, New York.

- (2013), The Posthuman, Polity Press, Cambridge.

Gaard Greta (2016), "Ecofeminism” [in:] Keywords for Environmental Studies, eds. Adamson J., Gleason W.A., Pellow D.N., New York UP, New York - London.

Haraway Donna (2016), A Cyborg Manifesto: Science, Technology, and Socialist-Feminism in the Late Twentieth Century, University of Minnesota Press, Minneapolis.

Merchant Carolyn (1989), The Death of Nature: Women, Ecology, and Scientific Revolution, Harper and Row, San Francisco.

Mies Maria, Shiva Vandana (2014), Ecofeminism, Zed Books, London - New York.

Mohr D.M. (2007), Transgressive Utopian Dystopias: The Postmodern Reappearance of Utopia in the Disguise of Dystopia, "Zeitschrift Für Anglistik Und Amerikanistik", vol. 55(1).

Moylan Tom (2000), Scraps of the Untainted Sky: Science Fiction, Utopia, Dystopia, Boulder, Westview.

The Book of Job, https://www.biblica.com/bible/nirv/job/36/ [access: 7.07.2020].

Vieira Fatima (2010), "The concept of utopia" [in:] The Cambridge Companion to Utopian Literature, ed. Claeys G., Cambridge UP, Cambridge. 